\title{
CONSIDERAÇÕES SOBRE O JUSPOSITIVISMO
}

\section{Reis Friede}

Desembargador Federal, diretor do Centro Cultural da Justiça Federal (CCJF), mestre e doutor em Direito. Professor e pesquisador do Programa de Mestrado em Desenvolvimento Local do Centro Universitário Augusto Motta (Unisuam), no Rio de Janeiro. Site: <https://reisfriede.wordpress.com/>. reisfriede@hotmail.com

\section{Resumo:}

0 debate que envolve 0 Jusnaturalismo e 0 Juspositivismo tem inspirado as reflexões de juristas e filósofos. Muito embora se possa afirmar que grande parte das históricas controvérsias associadas ao confronto entre o Direito Positivo e o Direito Natural já tenha sido superada, subsistem inúmeros aspectos que merecem uma dedicação acadêmica. Desse modo, o presente artigo analisa a contribuição conferida por diversos pensadores para 0 tema em questão.

\section{Palavras-chave:}

Teoria do Direito. Jusnaturalismo. Juspositivismo.

\section{CONSIDERATIONS ON THE JUSPOSITIVISM}

\section{Abstract:}

The debate regarding Jusnaturalism and Juspositivism has been inspiring the reflections of jurists and philosophers for a long time. Although it may be affirmed that a great deal of the historical controversies associated to the confrontation between the Positive Law and Natural Law has already been overcome, there are numerous aspects which deserve an academic dedication. Therefore, the current work analyses the contribution made by several thinkers about the subject matter.

\section{Keywords:}

Theory of Law. Jusnaturalism. Juspositivism. 
Recebido em: 5/10/2017

Aceito em: 24/10/2017

\section{Sumário:}

1 Introdução. 2 A Plurivocidade do Termo Positivismo. 3 A Transição do Jusnaturalismo para o Juspositivismo. 4 A Escola de Exegese e o Positivismo Jurídico. 5 A Escola Histórica do Direito e o Positivismo Jurídico. 60 Juspositivismo em Jeremy Bentham. 70 Juspositivismo em John Austin. 80 Juspositivismo em Hans Kelsen. 90 Juspositivismo em Alf Ross. 100 Juspositivismo em Herbert Hart. 11 Ronald Dworkin e a Crítica ao Positivismo. 12 Lon Luvois Fuller e a Moralidade Interna do Direito. 13 Wilfrid J. Waluchow e a Divisão no Positivismo Jurídico Contemporâneo. 14 Conclusão. 15 Referências. 


\section{INTRODUÇÃO}

De início, interessante registrar que Bobbio, fazendo alusão às pesquisas empreendidas por Kuttner, afirma que o primeiro uso da fórmula Direito Positivo (jus positivum) teria ocorrido pelas mãos de Abelardo, filósofo medieval do fim do século 11, registrando, outrossim, que investigaçôes anteriores apontavam que o emprego inaugural de tal expressão teria sido por Damaso, nos idos do século 12. Para Abelardo, segundo narra Bobbio (1995, p. 19), o Direito Positivo illud est quod ab hominibus istitutum, ou seja, apresenta como característica o fato de ser posto pelo ser humano, ao contrário do Direito Natural, posto por algo ou alguém que está além dele, como a natureza ou Deus.

Contemporaneamente, a expressão Direito Positivo pode ser definida como o conjunto de normas jurídicas estabelecidas com o fim de regular a vida em sociedade. É o Direito cuja elaboração depende da vontade humana, revelando-se por meio da forma escrita (lei) ou não escrita (norma consuetudinária, norma costumeira ou costume jurídico). É, ainda, o Direito institucionalizado, passível de ser imposto coercitivamente, abarcando a Constituição, as leis, os códigos, os tratados, as medidas provisórias, os decretos legislativos, as resoluçóes, os decretos, as portarias, etc.

Assim, a análise do Direito Positivo de um dado país permite compreender as nuances de uma sociedade, mormente se considerarmos a essência do brocardo ubi societas, ibi jus (“onde está a sociedade, está o Direito"). Com efeito, diante do poder soberano inerente ao Estado, cada país estabelece, no âmbito do respectivo território estatal, e em atenção à realidade social, o pertinente Direito Positivo, revelador, em última análise, do modo de ser de uma determinada comunidade.

Exatamente como ocorre em relação ao Jusnaturalismo, que experimentou diversas perspectivas teóricas ao longo do tempo, o Positivismo Jurídico, de seu lado, também comporta várias incursôes analíticas, reveladoras das mais diversas tendências explicativas, muitas das quais abrangentes de uma pluralidade de teses heterogêneas e até mesmo incompatíveis entre si, conforme será abordado. 


\section{A PLURIVOCIDADE DO TERMO POSITIVISMO}

Bobbio (1995, p. 15), ao definir o termo em destaque, adverte que não se deve confundi-lo com o denominado Positivismo Filosófico, explicando, ainda, que tal designação advém da expressão Direito Positivo, empregada em contraposição à noção de Direito Natural.

De sua parte, Diniz (2000, p. 102) também reconhece a plurivocidade do termo em exame, que tanto pode designar o chamado Positivismo Sociológico (ou Sociologismo Eclético, de Augusto Comte, bem como as perspectivas teóricas que a ele se assemelham), como o estrito Positivismo Jurídico, o qual, ao "arredar o direito natural, procura reconhecer tâo-somente o direito positivo, no sentido de direito vigente e eficaz em determinada sociedade, limitando assim o conhecimento científico-jurídico ao estudo das legislaçóes positivas, consideradas como fenômenos espácio-temporais".

\section{A TRANSIÇÃO DO JUSNATURALISMO PARA O JUSPOSITIVISMO}

O século 18 é mesmo crucial para o início do declínio das teorias jusnaturalistas, ocasião em que grandes filósofos e juristas começam a desenvolver diversas concepçóes juspositivistas do Direito, cujo aspecto central e comum corresponde exatamente à rejeição das ideias que apregoam a existência de um Direito Natural. Historicamente, conforme assevera Bobbio (1995, p. 27), a transição do Jusnaturalismo para o Juspositivismo guarda relação com a formação dos Estados modernos, fenômeno no qual se observou um processo de monopolização da produção jurídica por parte do Estado. Recorda o autor italiano que, naquele tempo, "a sociedade medieval era constituída por uma pluralidade de agrupamentos sociais, cada um deles dispondo de um Ordenamento Jurídico, produzido pela própria sociedade". Igualmente, Ferraz Jr. (2015, p. 49-51), ao advertir que "há um sentido filosófico e um sentido sociológico de positivaçáo", explica que o primeiro "designa o ato de positivar", vale dizer, a ação de "estabelecer um Direito por força de um ato de vontade", enquanto que a segunda significação traduz um fenômeno que, no século 19, "será representado pela crescente importância da lei votada pelos parlamentos como fonte do Direito". 
Sintetizando o pensamento daquela época, Aguiar (2004, p. 146) preceitua que a "colocação da lei no patamar de um comando estratificado, abstrato e absolutamente coercitivo atendia certamente ao reclamo da sociedade da época, em repúdio aos desmandos e extravagâncias produzidos pelo Absolutismo”. Com efeito, o valor da segurança jurídica, em tal conjuntura, adquire relevante dimensão, o que somente poderia ser alcançado pelo primado da lei. É neste contexto, pois, que surge o Positivismo Jurídico, em contraposição ao Jusnaturalismo. No mesmo sentido, Barzotto ilustra que o Positivismo Jurídico, enquadrado no paradigma cientificista, possui como promessa teórica a segurança:

No Estado Liberal, o valor dado à segurança alcança um patamar superior àquele realizado pelo Estado Absolutista. Neste último, o Estado fornece segurança contra a ação dos outros indivíduos. No Estado Liberal, a ordem jurídica garante a segurança do indivíduo contra o próprio Estado (BARZOTTO, 2007, p. 15).

A expressão Positivismo Jurídico, desse modo, pode ser sucintamente definida como a doutrina que inadmite a existência de qualquer outro Direito senão o Direito Positivo, isto é, aquele estabelecido pelo Estado, opondo-se, portanto, ao Jusnaturalismo. Nesse contexto, o Direito passa a ser concebido como decorrência da exclusiva vontade humana, fruto da atuaçáo estatal, revelando-se por intermédio da lei (concebida como a expressáo máxima da soberania popular), fenômeno que, segundo um segmento doutrinário, conduziu ao enfraquecimento teórico do Direito Natural, dado histórico observado, por exemplo, nas denominadas Escolas de Exegese (França) e Histórica do Direito (Alemanha), ambas entendidas, de um modo geral, como precursoras do Positivismo Jurídico, cuja construção teórica contou com as reflexóes de verdadeiros expoentes da Filosofia do Direito.

\section{A ESCOLA DE EXEGESE E O POSITIVISMO JURÍDICO}

A Escola de Exegese (que correspondeu, na Alemanha, à chamada Escola Histórica, e, na Inglaterra, à Escola Analítica) é frequentemente mencionada como uma das mais incipientes correntes positivistas surgidas ao longo da história do Direito. De seu inaugural surgimento na França do século 19, notadamente à época da promulgação do Código Napoleônico (1804), diploma mediante o qual se 
procedeu à unificação do Direito Civil do referido país, o Exegetismo - que reuniu os mais renomados juristas franceses daquela época, tais como Proudhon, Bugnet, Demolombe, Pothier e outros - difundiu-se pela Europa continental. Diniz, ao analisar as formulaçóes teóricas trazidas à baila pela Escola de Exegese, principalmente sob o prisma do dualismo Direito Natural - Direito Positivo, explica que:

\begin{abstract}
A ciência do direito, no século XIX, encontra sua expressão mais característica no exegetismo. Para a escola da exegese, a totalidade do direito positivo se identifica por completo com a lei escrita; com isso a ciência jurídica se apegou à tese de que a função específica do jurista era ater-se com rigor absoluto ao texto legal e revelar seu sentido. Todavia, é preciso não olvidar que o exegetismo não negou o direito natural, pois chegou a admitir que os códigos, elaborados de modo racional, eram expressão humana do direito natural, por isso o estudo do direito deveria reduzir-se à mera exegese dos códigos. Visavam os franceses à construção de um sistema normativo estruturado de acordo com as normas da natureza, com o escopo de assegurar os direitos subjetivos fundamentais do homem, que lhe eram inerentes. O estudo do Código Civil seria a concretização desse ideal jusnaturalista. A lei e o direito constituem uma mesma realidade, pois a única fonte do direito é a lei e tudo o que estiver estabelecido na lei é direito (DINIZ, 2000, p. 50).
\end{abstract}

Relativamente ao que interessa no âmbito de uma abordagem jusnaturalista/ juspositivista, impende registrar que a Escola de Exegese, em linhas gerais, defendeu uma nova concepção no modo pelo qual o Direito deveria ser interpretado pelo jurista, a quem competiria, sob tal perspectiva, tão somente aplicar as normas legais ditadas pela vontade do legislador, enfatizando, pois, o método de ensino jurídico calcado exclusivamente na lei, idealizada como genuína manifestação da vontade geral do povo.

\title{
5 A ESCOLA HISTÓRICA DO DIREITO E O POSITIVISMO JURÍDICO
}

Conforme destacado anteriormente, sob a perspectiva da Escola de Exegese, o Código nada deixava ao arbítrio do intérprete, sendo considerado, pois, uma obra absolutamente perfeita, entendimento que, por ser deveras equivocado, deu margem a rigorosas críticas ao exegetismo legalista. 
Leciona Nader (2017, p. 13) que a "Escola Histórica do Direito, de formação germânica, criada no início do século XIX, valorizou e deu grande impulso aos estudos históricos do Direito", sendo certo que, para esta Escola, "o Direito era um produto da História”.

Reale, ao situar temporalmente a Escola Histórica do Direito, alude às diversas conquistas tecnológicas alcançadas pela humanidade no decorrer do século 19, quando se "operou a revolução técnica, especialmente através dos grandes inventos no plano da Física e da Química e das aplicaçôes de natureza prática, notadamente através da utilização da força a vapor e, depois, da eletricidade", o que fez com que a vida social se alterasse profundamente, provocando, assim, um "compreensível desajuste entre a lei, codificada no início do século XIX, e a vida com novas facetas e novas tendências". Diante de tal transformação, explica Reale (2002, p. 283-284), as "pretensóes de 'plenitude legal' da Escola de Exegese pareceram pretensiosas", tendo em vista que, frequentemente, surgiam problemas sobres os quais os legisladores do Código Civil não haviam cogitado.

Por mais que os intérpretes forcejassem em extrair dos textos uma soluçáo para a vida, a vida sempre deixava um resto. Foi preciso, então, excogitar outras formas de adequação da lei à existência concreta.

Foi especialmente sobre a inspiração da Escola Histórica de Savigny que surgiu outro caminho, a chamada interpretação histórica. Sustentaram vários mestres que a lei é algo que representa uma realidade cultural - ou, para evitarmos a palavra cultura, que ainda não era empregada nesse sentido -, era uma realidade histórica que se situava, por conseguinte, na progressão do tempo. Uma lei nasce obedecendo a certos ditames, a determinadas aspiraçóes da sociedade, interpretadas pelos que a elaboram, mas o seu significado não é imutável (REALE, 2002, p. 283-284).

Venosa (2006, p. 56, 58-59), por sua vez, confere à Escola Histórica do Direito (representada, principalmente, pelos jusfilósofos alemáes Gustav Von Hugo, Friedrich Carl Von Savigny e Georg Friedrich Puchta) o mérito de ter, pela primeira vez, repelido frontalmente o Direito Natural, aumentando, assim, "o abismo entre a teoria e a prática do Direito, que vinha do início do Jusnaturalismo", de modo que "aquilo que a razão representara para os adeptos do Direito Natural passou a ser substituído pelos fenômenos históricos". 
Segundo afirma Ferraz Jr. (2015, p. 50-51), a contribuição de Gustav Von Hugo (1764-1844), professor da Universidade de Göttingen, para o tema em análise pode ser constatada logo no primeiro volume de seu Lehrbuch Eines Civilistischen Cursus, quando o ilustre professor alemão propôs, "segundo um paradigma kantiano, uma divisão tripartida do conhecimento científico do Direito, correspondente a três questóes fundamentais": a) Dogmática Jurídica ("o que deve ser reconhecido como de direito?"), b) Filosofia do Direito ("é racional que o reconhecido como de direito assim o seja?") e c) História do Direito ("como aquilo que é reconhecido como de direito se tornou tal?").

Gustav Von Hugo, criticando a teoria jusnaturalista baseada na razáo, procura desenvolver, metodologicamente, uma nova sistemática da Ciência Jurídica, na qual a dimensão histórica da relação jurídica passa a ser um ponto fundamental.

Friedrich Carl Von Savigny (1779-1861), reputado como aquele que efetivamente desenvolveu a aludida Escola Histórica, aprofunda as reflexóes de Gustav Von Hugo sobre tal método, notadamente a partir dos seguintes aspectos críticos: de início, opôe-se à codificação do Direito, "por considerá-lo como manifestação característica da livre consciência do povo ou do espírito popular, sob a forma do costume, e não como um produto racional do legislador". Ademais, o Direito, na ótica de Savigny, "surge na história como decorrência dos usos e costumes e da tradiçáa", o que significa dizer que o "legislador não cria o Direito, apenas traduz em normas escritas o Direito vivo, latente no espírito popular, que se forma através da história desse povo, como resultado de suas aspiraçóes e necessidades”. Diante da concepção savignista, o Direito não seria criação arbitrária da vontade estatal, mas, sim, "produto da consciência popular (Volksgeist), em determinadas condições de tempo e lugar, da qual o costume é a manifestaçáo autêntica, livre e direta”. Assim, exatamente como sucede com a língua, que "principia espontaneamente no modo de falar de um povo", o Direito, na perspectiva de Carl Von Savigny, "também começa como conduta consuetudinária popular”, ou seja, "a partir da convicção espontânea do povo a respeito do que se entende por necessário e justo” (DINIZ, 2000, p. 98).

Nesta conjuntura de profundas mudanças experimentadas pelo mundo de outrora, especialmente no que se refere ao fenômeno da codificação, a doutrina alude ao paradigmático embate travado entre Carl Von Savigny e Anton Friedrich Justus Thibaut (1772-1840), outro jurista alemão da mesma época, professor da Universidade de Heidelberg, famoso por defender, exatamente como ocorrera na França em 1804, a adoção do mesmo modelo codicista no âmbito do Direito Alemão: 
Por um lado, Thibaut era favorável à codificação para facilitar a integração alemã, nos moldes do que ocorrera na França, por ocasiáo do surgimento do Código Napoleônico. Por sua vez, Savigny era contrário ao legalismo produzido com base no modelo codicista francês, propugnando, ao revés, a formação histórica do direito como decorrência da evolução espontânea dos costumes, produto do chamado espírito do povo (Volksgeist). Foi assim que Savigny inaugurou e consolidou a Escola Histórica do Direito, também conhecida como o historicismo jurídico (SOARES, 2013, p. 158).

Com efeito, Thibaut, na obra intitulada Sobre a Necessidade de um Direito Civil Geral para a Alemanha (Über die Notwendigkeit eines allgemeinen bürgerlichen Rechts für Deutschland, 1814), "fundamentando-se nos muitos inconvenientes políticos e comerciais que ocorriam em razão das disparidades existentes entre as leis e os costumes dos Estados alemães" (CASTILHO, 2017, p. 116), e tendo como modelo o Código Napoleônico de 1804, pugnava pela criaçáo de um codex comum para todos os Estados germânicos, iniciativa (de natureza nitidamente iluminista) que enfrentou forte oposição de Savigny, que rechaçou tal proposta, publicando, em contraposição teórica, um texto denominado Da Vocação de Nosso Século para a Legislaçâo e a Jurisprudência (Vom Beruf unserer Zeit für Gesetzgebung und Rechtswissenschaft, 1814), no qual se declara contrário aos propósitos de Thibaut, enfatizando, em linhas gerais, a primazia dos costumes do povo (e de sua história) como fonte primária do Direito.

Soares (2013, p. 159), ao empreender uma análise das teses defendidas pelo Historicismo Jurídico, “afirma que seu grande mérito foi situar o Direito corretamente na zona ôntica dos objetos reais e, particularmente, culturais, afastando-se da influência metafísica do positivismo legalista, que colocava o Direito no campo dos objetos ideais".

\section{JUSPOSITIVISMO EM JEREMY BENTHAM}

O inglês Jeremy Bentham (1748-1832), nos termos de sua Teoria Utilitarista do Direito, argumenta que as normas jurídicas devem ser interpretadas sob o prisma dos efeitos produzidos quando de sua incidência concreta. Assim, na 
ótica de Bentham, justa é a norma que, uma vez aplicada, produz efeitos bons; ao contrário, aquela cuja incidência concreta acarreta consequências ruins deve ser reputada como injusta.

Jeremy Benthan é considerado como o principal responsável pelo fortalecimento do utilitarismo na sociedade, e sua influência hoje é maior do que nunca. Todos os autores que abordam questóes relativas à análise de custo/benefício têm para com Bentham uma dívida intelectual (EDMUNDSON, 2006, p. 72).

Nota-se, pois, que o critério adotado por Bentham, para o fim de qualificação dos aludidos resultados, consiste exatamente na noção de utilidade. Destarte, bom, na ótica do referido pensador inglês, é o que produz prazer; mau, por sua vez, o que causa dor. No plano social, bom ou justo é o que tende a aumentar a felicidade de todos ou, pelo menos, de um grande número de pessoas (DINIZ, 2000, p. 58).

Bentham admite apenas o sentido "objetivo" de direito, identificado pelos juristas medievais. Porém, mesmo neste sentido, o conceito ainda está sujeito a uma construção utilitarista. O que é direito é apenas o que é vantajoso para a sociedade, de onde se segue que nada é imprescritível - quando acaba a vantagem, acaba também o direito. "Direito" e "vantajoso para a sociedade" são termos coextensivos. É só nesta base que Bentham admite qualquer discussão sobre "direito" fora do âmbito legal (EDMUNDSON, 2006, p. 76).

Explica Dias (2015, p. 147-166) que, "por ser conforme uma noção de natureza humana que busca o prazer e foge da dor", o princípio de utilidade "reconhece que os homens agem de acordo com determinadas finalidades, segundo seus interesses, e coloca como norma que os indivíduos busquem seu prazer ou seus interesses". No mesmo sentido, ensinam Marcondes e Struchiner (2007, p. 116) que, de acordo com o princípio de utilidade, "o bem seria aquilo que maximiza o benefício e reduz a dor ou o sofrimento", do que se depreende que "terão mais valor de um ponto de vista ético as açóes que beneficiarem o maior número de pessoas possível”.

No que respeita especificamente ao embate entre Jusnaturalismo e Positivismo, cabe mencionar que Bentham, em sintonia (no seu aspecto global) com as premissas do Utilitarismo, formulou críticas ao Direito Natural, justamente por 
entender que as leis são fruto da vontade humana, consistindo, ademais, em meios que possibilitam a consecução de determinados fins (princípio de utilidade). Com efeito, Bentham entende que "não há direitos naturais em contraposição ou distinção aos legais, sendo a expressão uma mera figura de linguagem; e que, quando se emprega essa expressão, no momento que se tenta dar-lhe sentido literal, o resultado é o erro - o tipo de erro que leva à perniciosidade, ao extremo da perniciosidade" (EDMUNDSON, 2006, p. 75).

\section{JUSPOSITIVISMO EM JOHN AUSTIN}

O inglês John Austin (1790-1858), a partir de influências teóricas advindas, principalmente, de Jeremy Bentham, mostrou-se preocupado em introduzir um enfoque analítico no âmbito da Teoria do Direito, tendo publicado, em 1832, aquela que é considerada sua mais relevante obra, fruto das dez primeiras liçóes que havia proferido na Universidade de Londres: A Delimitação do Objeto do Direito (The Province of Jurisprudence Determined).

Contrapondo-se aos rumos jusnaturalistas de sua época, Austin empreendeu esforços no sentido de estabelecer - organizada, sistemática e analiticamente - os aspectos conceituais do Direito, buscando promover a separação entre este e a Moral, embora admitisse a existência de conteúdos morais no âmbito do sistema jurídico. De fato o Direito, afirma Austin, existe independentemente de ser injusto, isto é, sua validade deve ser aferida sob o aspecto conceitual, e não a partir de fundamentos morais. Uma lei existente, argumenta Austin, existe, ou seja, é lei, ainda que a aprovemos ou náo.

De acordo com as lições de Edmundson, Austin não admirava a expressão Direito Natural, tendo em vista que, na sua ótica, tal locução ensejava uma "analogia com as leis da natureza - tais como as da Física”, devendo, pois, ser evitada.

Se o apelo aos direitos "naturais" é apenas um apelo à moralidade, então os direitos naturais não passam de direitos morais. Mas "moralidade" é também um termo ambíguo. No entender de Austin, ele pode se referir tanto ao código moral convencional, ou positivo, da comunidade, como ao código moral ideal proclamado por Deus. Se o apelo for à consciência moral - ainda em 
desenvolvimento, da comunidade, ele deve ser entendido como referente a um “direito divino". Há dois tipos de direito divino: o revelado e o não revelado. Os direitos divinos revelados encontram-se no âmbito da lei divina revelada, isto é, em mandamentos ou escritos bíblicos de inspiração divina (EDMUNDSON, 2006, p. 87).

Austin é destacado por ter concebido - a partir de inspiração teórica buscada nas reflexóes de Jeremy Bentham - o Direito como um autêntico conjunto de comandos/ordens (amparados na ideia de coerção) oriundos do soberano no exercício do seu poder ilimitado (Teoria Imperativa do Direito), razão pela qual, na visão austiniana, este não se submete ao próprio Direito por ele estabelecido, podendo utilizá-lo, portanto, como um instrumento de poder.

Austin assume como tarefa de sua formulação teórica separar o objeto do direito dos elementos que frequentemente são tomados equivocadamente como jurídicos. Para tanto, apresenta a noção de soberano como central, tornando-a, conjuntamente com as de "comando", "sanção" e "hábito de obediência”, os elementos do que designa ser a "chave da teoria do direito". Com efeito, procede nosso autor diferenciaçóes finas a respeito "das leis" em geral até alcançar lista que considera ser o foco da análise do estudo do Direito. A partir desse ponto, descreve as características do soberano e a importância dos componentes elementares do Direito. Nesse contexto, a idéia de comando e de sanção mantém relaçóes próximas com a noção de soberano. Porque o comando é a ordem ou desejo editado ou pronunciado pelo soberano, e sanção é a conseqüência; e esta manifestação do poder do soberano corresponde ao mal que ele pode infligir se o seu desejo é ignorado ou desobedecido, com o que sua teoria afigura-se de extrema simplicidade e clareza: se uma norma $N$ pertence a uma ordem jurídica $O J$, isso significa que ela, a norma $N$, foi ditada pelo soberano (SGARBI, 2006, p. 28).

Nesse contexto, cumpre ao juiz, ao decidir os mais diversos casos que se lhe apresentam, aplicar exatamente o comando advindo do soberano. Náo obstante, diante da inexistência de um comando ajustável ao caso concreto, deve o juiz resolvê-lo como julgar mais adequado, posto que tacitamente autorizado a fazê-lo pelo 
mesmo soberano. Com efeito, sob o prisma de tal construção teórica de Austin, a autorização tácita para decidir acaba por tornar tais decisões tomadas pelos juízes em autênticos comandos do soberano.

\section{JUSPOSITIVISMO EM HANS KELSEN}

Morrison, ao discorrer a respeito da visão crítica de Kelsen (1881-1973) em relação à teoria anterior, afirma que o professor austríaco "interpreta Austin como um empirista relativamente simples, o que significa que Austin interrompeu sua análise no nível descritivo geral, sem proceder aos atos interpretativos necessários à contemplação da natureza especificamente jurídica da atividade social observada", asseverando, ademais, o seguinte:

Em essência, Kelsen acusa Austin de não ter compreendido a estrutura normativa da legalidade, e argumenta que, no fim, a teoria austiniana pretendeu extrair uma série de proposiçōes "dever-ser" de proposiçōes "ser" [...]. As unidades estruturais básicas da teoria de Austin eram observaçóes de fatos sociais, a redução da ideia de regras de obrigaçóes aos comandos de um soberano e aplicação desses comandos; à procura de dados empíricos para criar uma ciência do Direito, o observador se dava conta das regularidades de um soberano que costumava ser obedecido e não obedecia a ninguém, e que comandava sujeitos que habitualmente obedeciam. Kelsen, porém, perguntou: "De que modo isso descreve o processo por meio do qual alguém deve obedecer ao Direito?”

Para Kelsen, as regras eram as características observáveis (na escrita, etc.) de um sistema normativo. As regras eram, portanto, as características de superfície do Direito, e as normas sua essência interior; conquanto elas possam ter dado origem aos atos de "vontade" de um Parlamento, ou à adoçấo de um costume por um juiz, uma vez aceitas como direitos adquirem existência independente; sua validade não depende da vontade de um mandatário: "uma norma é uma regra que afirma que o indivíduo deve comportar-se de uma determinada maneira sem afirmar, porém, que tal comportamento seja a vontade específica de alguém” (MORRISON, 2012, p. 391-392). 
A principal obra de Hans Kelsen é, sem sombra de dúvida, a conhecida Teoria Pura do Direito (1934). Segundo o entendimento de Morrison (2012, p. 411), tal produção teórica "fala a uma modernidade que está lidando com a democracia, o perspectivismo e a indeterminação do objetivo social”, sendo claramente identificada por Kelsen "como um projeto de direito antinatural". Na realidade, convém salientar, a Teoria Pura "não é apenas o nome de um livro, mas de um projeto", tendo em vista que a pretensão de Kelsen, em última análise, era conduzir o Direito ao status de Ciência Jurídica, intento que, de certa forma, acompanhou toda a trajetória acadêmica do formidável pensador austríaco, cujo escopo teórico sempre consistiu em "estabelecer limites claros, além de respostas, ainda que nem sempre bem acabadas, ao seu maior propósito", vale dizer, "a elaboração de uma teoria do direito positivo que fosse independente dos particularismos da realidade de cada país" (SGARBI, 2006, p. 31). Por oportuno, conforme mencionado pelo próprio Kelsen:

A Teoria Pura do Direito é uma teoria do Direito Positivo - do Direito Positivo em geral, não de uma ordem jurídica especial. É teoria geral do Direito, não interpretação de particulares normas jurídicas, nacionais ou internacionais. Contudo, fornece uma teoria da interpretação.

Como teoria, quer única e exclusivamente conhecer o seu próprio objeto. Procura responder a esta questão: o que é e como é o Direito? Mas já não lhe importa a questão de saber como deve ser o Direito, ou como deve ele ser feito. É ciência jurídica e não política do Direito (KELSEN, 1987, p. 1).

Assim, segundo explica Sgarbi (2006, p. 33), o vocábulo pura é "palavra que expressa o que os teóricos do Direito ainda não conseguiram obter, mas que cumpre a ele, Kelsen, viabilizar", isto é, uma "leitura específica da juridicidade, sem interferências de outros campos do conhecimento que não agem na precisa delimitação do Direito", inclusive o pertinente à moral. No mesmo sentido, Bugallo aduz que

Kelsen, por sua vez, destaca que seu objetivo é construir "uma teoria do direito positivo", do direito positivo "em geral, não de uma ordem jurídica especial". Portanto, "teoria geral do direito, não interpretação de particulares normas jurídicas", embora "forneça uma teoria da interpretaçáo". "Como teoria, quer única e exclusivamente conhecer o seu próprio objeto”. Teoria do direito posi- 
tivo, isto é, do direito "que é e como é", não do direito que deveria ou poderia ser. Destaca o específico da juridicidade, o dever ser, em seu aspecto formal, e, portanto, permanente, controlável e aferível. Por outro lado, no referente ao processo de produçáo, o aspecto formal, via de regra, é o fator determinante da validade, e, portanto, da juridicidade, na medida em que, em princípio, a validade de uma norma náo depende de seu conteúdo. Ao limitar o objeto da teoria ao direito em sua especificidade, enunciado como modelo de conduta devida, independentemente de seu conteúdo, configurou a natureza pura da teoria e a razão do princípio da neutralidade na construção do conhecimento jurídico. A norma fundamental posta e especialmente a pressuposta, que não tem conteúdo nem é produzida por ninguém, constitui-se na categoria explicativa e legitimadora do sistema. Portanto, em Kelsen, o direito é fenômeno social, que regula sua própria produção e aplicaçáo, produzido ou sancionado pelo Estado, configurando uma ordem normativa coativa e que dispõe de critérios de aferição da juridicidade (validade), que, por princípio, não depende do conteúdo ou autoridade externa ao próprio direito (BUGALLO, 2009, p. 11-12).

Com o advento da Teoria Pura do Direito, conforme explica Soares (2013, p. 162), "o Positivismo Jurídico converte-se em uma variante do normativismo lógico, aprofundando o distanciamento da Ciência do Direito em face das dimensóes valorativa e fática do fenômeno jurídico". Da mesma forma, a aludida Teoria Pura, nas palavras de Soares (2013, p. 162), configura uma nítida "reação ao sincretismo epistemológico no conhecimento jurídico", tendo como escopo último afirmar "a autonomia e a especificidade metódica da Ciência do Direito", aspectos que, na ótica de Kelsen, encontravam-se comprometidos "seja pela tentativa metafísica do jusnaturalismo de convertê-la em uma filosofia da justiça”, seja pelo propósito "empirista do historicismo e do sociologismo jurídico de subordiná-la a outras ciências que cuidam dos fatos sociais, tais como a história e a sociologia".

A concepção kelseniana envolve, ademais, a Teoria da Norma Jurídica (na qual a norma jurídica é estudada como sentido objetivo de um ato criador de Direito dotado de validez) e a Teoria do Ordenamento Jurídico, identificado como um sistema de normas, disposto hierarquicamente como uma pirâmide, no qual a validade de uma norma inferior depende de uma norma superior, que estabelece os critérios formais e materiais para sua produção (SOARES, 2013, p. 163). Assim, consoante as formulaçôes teóricas de Kelsen, "dizer que uma norma é válida 
é o mesmo que dizer que existe no conjunto normativo e que, por existir, deve ser obedecida e aplicada juridicamente" (SGARBI, 2006, p. 41), do que se conclui que, na visão de Kelsen, náo cabe à ciência do Direito responder o que é justo ou conforme a justiça.

Dissertando sobre a validade da norma sob a perspectiva de Kelsen, Bugallo registra que "a validade é construída em função de elemento tipicamente kelseniano, isto é, o formal".

Como princípio metodológico, Kelsen trata do direito em sua especificidade, isto é, naquilo que configura a juridicidade e, como bom positivista, naquilo que na juridicidade existe de permanente, porque só o permanente é identificável no tempo e aferível. Ora, o permanente, na norma, não está no fato social, político ou fator axiológico, por se tratar de elementos mutáveis, mas na forma, no dever ser, isto é, enunciado de uma conduta devida, que pode ter qualquer conteúdo e, portanto, conter qualquer valor. Tal fator é a validade, a ser aferida, na dinâmica jurídica, pelo processo de produção e dimensionada pelo aspecto formal: a competência. Desta forma, conclui Kelsen, uma norma é válida, se produzida de acordo com o processo estabelecido por outra norma, razão porque a norma produzida tem seu fundamento de validade na norma que regula seu processo de produção (2009, p. 21-22).

A respeito da separação entre Direito e Moral, asseveram Bittar e Almeida que "validade e justiça de uma norma jurídica são juízos de valor diversos", concluindo os autores, então, que "uma norma pode ser válida e justa; válida e injusta; inválida e justa; inválida e injusta”.

O Direito possui a nota característica de poder ser moral (Direito justo), e de poder não ser moral (Direito injusto); e, certamente, prefere-se o Direito moral ao imoral, porém não é isso que retira validade de determinado sistema jurídico. Um Direito positivo pode ser justo ou injusto, ou seja, um Direito positivo sempre pode contrariar algum mandamento de justiça, e nem por isso deixa de ser válido. O Direito náo precisa respeitar o mínimo moral para ser definido e aceito como tal, pois a natureza do Direito, para ser garantido em sua construção, não requer nada além do valor jurídico. Mais uma vez, deve- 
-se afirmar que o que foi posto pelo legislador é norma jurídica, se consignado internamente no ordenamento jurídico dentro dos moldes procedimentais e hierárquicos suficientes para tanto.

Assim, a conclusão acerca da relação entre Direito e Moral não pode ser outra senão a de que: "A exigência de uma separação entre Direito e Moral, Direito e Justiça, significa que a validade de uma ordem jurídica positiva é independente desta Moral Absoluta, única válida, da Moral por excelência, de $a$ Moral”. Assim, é válida a ordem jurídica ainda que contrarie os alicerces morais. Validade e justiça de uma norma jurídica são juízos de valor diversos, portanto (uma norma pode ser válida e justa; válida e injusta; inválida e justa; inválida e injusta) (BITTAR; ALMEIDA, 2011, p. 396).

Como se observa, "a autonomia do Direito, para Kelsen, só se alcança isolando o jurídico do não jurídico", o que significa afirmar "que o Direito, como ciência, deve significar um estudo lógico-estrutural, seja da norma jurídica, seja do sistema jurídico de normas". Em tal contexto, a "interpretação se torna um ato de definição dos possíveis sentidos da norma jurídica”; com efeito, a "interpretação do juiz, ato prudencial, por natureza, para Kelsen, transforma-se no ato da criação de uma norma individual" (BITTAR; ALMEIDA, 2011, p. 402).

Ainda de acordo com Kelsen (1990, p. 13), o Direito não estaria vinculado a qualquer regime político ideal, posto que, "do ponto de vista da ciência, livre de quaisquer julgamentos valorativos, morais ou políticos, a democracia e o liberalismo são apenas dois princípios possíveis de organização social, exatamente como o são a autocracia e o socialismo", não havendo, pois, "razão científica pela qual o conceito de Direito deva ser definido de modo a excluir estes últimos"; afinal, prossegue Kelsen, "o conceito de Direito não tem quaisquer conotaçóes morais".

\section{JUSPOSITIVISMO EM ALF ROSS}

Alf Niels Christian Ross (1899-1979), jurista e filósofo dinamarquês, é reconhecido como um dos fundadores do Realismo Jurídico Escandinavo, corrente do pensamento jusfilosófico que concebe o Direito como um conjunto de fatos ou fenômenos psicofísicos, cujo estudo, portanto, deve seguir os "padrôes tradicionais 
de observação e de verificação que animam toda a moderna ciência empirista" (ROSS apud SGARBI, 2006, p. 65), de modo a livrar o pensamento jurídico de uma série de pressupostos não examináveis e não alicerçados na ciência.

Alf Ross, referido por Bugallo (2009, p. 11), recusa a filosofia do Direito Natural por se tratar, segundo ele, de uma especulação metafísica e desprovida de justificação científica, do que se extrai, por conseguinte, que o "único Direito é o Direito Positivo, compreendido como um conjunto coerente de normas vigentes, isto é, efetivas, portanto, observáveis e constatáveis, aferíveis e operacionalizadas através das decisóes judiciais com base em diretivas de competência”. Assim, a proposta de Ross é "desmistificar o Direito e as categorias com que este é tradicionalmente pensado"; para tanto, parte o professor dinamarquês de "uma concepção empirista e antimetafísica do conhecimento", sendo o "Direito entendido como uma fusão de dois elementos", a saber: "(10) a realidade social que se manifesta por meio da aplicação, pelos juízes, do Direito positivado, e (2) as normas que funcionam como um esquema para entender as açóes dos juízes” (STOLZ, 2007, p. 115).

Enfim, Alf Ross, em quatro capítulos da obra Sobre o Direito e a Justiça (1953), aborda e critica as diversas correntes fundamentadoras do Direito Natural, afirmando, em síntese, que tais perspectivas teóricas não se submetem a "critérios de verificação ou falsificação", razão pela qual conclui que "as asserçôes metafísicas relativas às doutrinas do Direito Natural colocam-nas acima de toda força de controle intersubjetivo e deixam a porta aberta para a imaginação ilimitada e o dogmatismo" (SGARBI, 2006, p. 99).

\section{JUSPOSITIVISMO EM HERBERT HART}

Foi referido anteriormente que Jeremy Bentham e John Austin, no que se refere ao assunto ora discorrido, são considerados autores positivistas imperativistas, tendo em vista que ambos acolhem uma noção comum, segundo a qual o Direito é fruto da vontade do soberano, tese centrada nas ideias de comando e coerção, concepção esta que, diferentemente, não pode ser atribuída ao inglês Herbert Lionel Adolphous Hart (ou H. L. A. HART, 1907-1992), jurista e filósofo do Direito, autor reconhecidamente importante para uma nova tomada de posição em relação 
às Filosofia e Teoria do Direito. Hart, neste contexto, rejeita a denominada Teoria Imperativista, cuja característica fundamental, conforme consignado, consiste justamente em vincular o Direito às noçôes de comando e coerçâo. Em O Conceito de Direito, obra publicada em 1961, Hart afirma que o termo positivismo, na literatura anglo-americana contemporânea, é empregado para traduzir uma ou mais das seguintes afirmaçóes teóricas:

1) que as leis são comandos de seres humanos; 2) que não há vínculo necessário entre direito e moral ou entre o direito como ele é e o direito como deve ser; 3) que a análise ou estudo do significado dos conceitos jurídicos é um estudo importante, que deve ser distinguido (apesar de náo ser contrário a elas) das pesquisas históricas e sociológicas e da avaliação crítica do direito em termos de moral, objetivos e funçôes sociais, etc.; 4) que um sistema jurídico é um "sistema lógico fechado", no qual decisóes corretas podem ser deduzidas por meios exclusivamente lógicos a partir de normas jurídicas predeterminadas; 5) que os juízos morais náo podem ser demonstrados, como podem os enunciados factuais, por meio de argumentação racional, evidência ou prova [...]. Bentham e Austin defendiam as opiniões expressas em (1), (2) e (3), mas não aquelas em (4) e (5); Kelsen defende aquelas expressas em (2), (3) e (5), mas não as apresentadas em (1) e (4). A afirmação (4) é geralmente atribuída aos "juristas analíticos", aparentemente sem boas razóes (HART, 2009, p. 386-387).

Hart, pelo que se observa no item 2 da transcrição supra, demonstra que, a seu ver, não há necessariamente um vínculo entre Direito e moral, o que o situa, segundo um segmento doutrinário, entre os autores positivistas inclusivistas (ou positivistas incorporacionistas). Significa dizer que Hart admite que conceitos e normas próprios do Direito possam incorporar regras pertinentes ao campo da moral, desde que o sistema jurídico o autorize.

Ademais, em $O$ Conceito de Direito, Hart contesta a aludida teoria do comando, delineada por Austin na obra The Province of Jurisprudence Determined ( $A$ Delimitaçáo do Objeto do Direito, 1832), cujos contornos fundamentais consagram a ideia de que o Direito caracteriza-se por abarcar um conjunto de comandos e ameaças estabelecidos por um soberano. Hart, partindo de uma distinção entre "ter a obrigaçâo de fazer algo" e "ser obrigado a fazer algo", e adotando como exemplo a conduta ameaçadora de um assaltante, afirma que, na verdade, inexiste obrigação 
quando o único motivo para obedecer é a ameaça, exatamente o que acontece no caso de um assalto. Diferentemente da intimidaçáo contida na açáo do assaltante, o Direito estabelece normas de agir aptas a orientar o comportamento não apenas daqueles aos quais as orientaçóes normativas são destinadas, mas também aos funcionários públicos encarregados da aplicação de tais diretrizes. Com efeito Hart, de um modo geral, opóe as seguintes objeções ao arquétipo teórico austiniano:

Os fracassos principais da teoria [de Austin] são suficientemente instrutivos para justificar um segundo resumo. Primeiro, ficou claro que, conquanto a lei penal - que proíbe ou impóe determinados atos sob ameaça de punição - dentre todas as formas do direito seja a que mais se pareça com as ordens apoiadas por ameaças dadas por uma pessoa a outras, ela difere dessas ordens sobre o aspecto importante de que normalmente se aplica também àqueles que a editam, e não apenas a terceiros. Em segundo lugar, há outros tipos de lei ou modalidade do direito, especialmente as que outorgam poderes jurídicos para exarar decisões ou legislar (poderes públicos), ou para criar ou modificar relaçôes jurídicas (poderes particulares) - modalidades essas que não podem, por absurdo, ser assimilados às ordens apoiadas em ameaças. Em terceiro lugar, algumas normas jurídicas diferem das ordens quanto à sua origem, pois não foi por prescrição explícita, nem por nenhum modo análogo, que vieram a existir. Finalmente, a análise do direito em termos de um soberano habitualmente obedecido e necessariamente isento de qualquer limitação jurídica não pôde explicar a continuidade da autoridade legislativa, continuidade essa que é característica dos sistemas jurídicos modernos; e a pessoa ou pessoas soberanas não puderam ser identificadas nem com o eleitorado, nem com o poder legislativo de um Estado moderno (HART apud MARCONDES; STRUCHINER, 2015, p. 98).

Ademais Hart, ao empreender uma análise crítica a respeito da teoria de Austin, desdobra-a em três segmentos. De início, estabelece uma distinção entre as noçóes de comando e regra. Em seguida, procura demonstrar que os sistemas jurídicos são integrados por várias espécies de regras, e algumas delas, como mencionado anteriormente pelo próprio Hart, nem de longe se assemelham aos citados comandos da teoria austiniana. E, por fim, Hart enfrenta as noções de soberano, súdito e hábito de obediência, concluindo que tais categorias são insuficientes para definir como funcionam as regras jurídicas. Desta forma, enquanto Bentham e Austin funda- 
mentam os respectivos pensamentos teóricos na noção de comando oriundo de um soberano, Hart, por sua vez, argumenta que o Direito constitui-se em um sistema composto por regras primárias e secundárias, modelo assim abreviado por Stolz:

Para Hart, o ordenamento jurídico é formado por um conjunto de regras que ele denomina de regras primárias e por três tipos de regras secundárias: regras de reconhecimento, regras de alteração/modificaçāo e regras de adjudicação. As regras primárias prescrevem o que os indivíduos podem ou não fazer e quando devem omitir certas ações - queiram ou não - ou seja, são regras que impóem deveres em sentido positivo e negativo. Já as regras secundárias, ademais de desempenhar distintas funçôes no ordenamento jurídico, são também o remédio para cada um dos defeitos que, inevitavelmente, apresentam um sistema composto somente por regras primárias, entre os quais se encontram: a falta de certeza, a dificuldade para assimilar as mudanças (sociais, culturais, econômicas, etc.) ocorridas na sociedade e a ineficácia da pressão social difusa que se exerce com a intenção de que se cumpram as normas. As regras secundárias de alteração outorgam competência a determinados sujeitos para que ajustem - por meio da introduçáo, exclusão e modificação de normas - a realidade social em que operam. Por sua vez, as regras de adjudicação dão dinamicidade e eficácia ao ordenamento jurídico, pois conferem potestades jurisdicionais - identificam e estabelecem quais são os indivíduos que podem julgar e os procedimentos que necessariamente devem seguir juízes e tribunais [...].

A fim de complementar a estrutura fundacional da sua teoria, Hart cria a noçáo de rule of recognition [regra de reconhecimento], que pretende ser um remédio para a falta de certeza do regime de regras primárias, bem como o instrumento adequado para a identificação de todo o material jurídico, de modo que o status de uma norma como membro do sistema dependa de que ela satisfaça certos critérios de validez estabelecidos na regra de reconhecimento. Dita regra, ademais, é uma norma última que subministra um critério jurídico de validez supremo. Neste sentido, todas as normas identificadas com referência a este critério são reconhecidas como normas válidas do ordenamento jurídico. Não obstante, é mister enfatizar que uma norma subordinada pode ser válida ainda que não seja geralmente obedecida, mas uma regra de reconhecimento não pode ser válida $\mathrm{e}$ rotineiramente desobedecida, pois ela somente existe como uma prática social eficaz e complexa. Entâo, uma regra de reconhecimento existirá como questáo de 
fato se, e somente se, é eficaz. Para a verificação do grau de eficácia da regra de reconhecimento se exige, ademais do cumprimento, a aceitação da mesma por seus destinatários, ou seja, que eles a considerem como pauta correta de conduta. A regra de reconhecimento náo só estipula a forma que todas as normas jurídicas devem assumir para serem consideradas normas válidas do sistema jurídico, mas também atribui competência e/ou autoridade a certos sujeitos para que ditem e apliquem as normas jurídicas fixando - com base nos direitos fundamentais dos cidadãos e na estrutura política do Estado - os limites de atuação dos poderes públicos. Decisivamente, é a presença da regra de reconhecimento que articula a idéia de sistema jurídico, ou seja, é ela que distingue o Direito de outros sistemas normativos, como a moral, as regras de trato social e as regras de jogo - dado que estes sistemas não dispóem, em seu interior, de uma regra última que identifique toda e cada uma das normas existentes estabelecendo a sua pertinência e validez (STOLZ, 2007, p. 101-120).

\section{RONALD DWORKIN E A CRÍTICA AO POSITIVISMO}

No domínio da temática versada no presente texto, cumpre consignar um aspecto das críticas direcionadas pelo norte-americano Ronald Dworkin (1931-2013), professor de Teoria Geral do Direito e Jurisprudência das Universidades de Nova York (EUA) e Oxford (Inglaterra), ao modelo de Positivismo Jurídico preconizado por Herbert Hart, censura que, em resumo, assevera que as concepçóes hartianas não são aptas para definir uma doutrina verdadeiramente eficaz sobre a essência do Direito. Para Dworkin, em contraste com a percepção de Hart, o Direito não pode ser concebido apenas como um conjunto de regras, sendo integrado, igualmente, por princípios, posto que reduzir o "fenômeno normativo às regras gera prejuízos no que diz respeito à argumentação, debate e balanceamento de razóes na prática jurídica” (SGARBI, 2006, p. 153).

Assim, segundo Dworkin (2002, p. 27-28), é possível sintetizar os pilares sobre os quais se assenta o Positivismo Jurídico: a) em primeiro lugar, é preciso reconhecer o Direito como um conjunto de regras jurídicas utilizado pela comunidade a fim de estabelecer qual comportamento será punido ou coagido pelo poder público, regras que deveráo ser cotejadas quanto à sua validade; $b$ ) ademais, diante da ausência, no âmbito do próprio Direito, de uma regra claramente apta 
a solucionar o caso concreto, deve a autoridade pública (leia-se, o juiz), exercendo seu discernimento pessoal, buscar, além do Direito, um novo padrão que o oriente na elaboração de uma nova regra jurídica; $\boldsymbol{c}$ ) por fim, consoante argumentação de Dworkin, o conceito de obrigaçáo jurídica está diretamente relacionado às regras jurídicas válidas, que exigem uma ação ou omissão dos sujeitos. Notadamente quanto ao exposto na letra $b$ (supra), é lícito concluir que o ilustre jusfilósofo norte-americano pretendeu comprovar que o primado da lei não é suficientemente capaz de conceber uma soluçáo aceitável para todos os casos, mormente para os chamados casos difíceis (hard cases).

Dworkin, ao analisar a teoria hartiana, aborda o emblemático caso (Riggs versus Palmer), ocorrido em 1882 nos EUA, no qual, em síntese, debateu-se sobre a possibilidade de um herdeiro (homicida) receber o que lhe fora deixado em testamento pelo testador, na hipótese em que a vida deste é injustamente ceifada por aquele, tudo com o torpe propósito de herdar. No caso em comento, Elmer Palmer figurava como o principal beneficiário da herança a ser deixada por seu avô (e sua vítima), o senhor Riggs.

Após muita discussão, a Corte de Apelação do Estado de Nova York decidiu pela exclusão de Palmer do recebimento da herança, sob o argumento de que a ninguém é "permitido lucrar com sua própria fraude, beneficiar-se com seus próprios atos ilícitos, basear qualquer reivindicação na sua própria iniqüidade ou adquirir bens em decorrência de seu próprio crime" (DWORKIN, 2002, p. 37). Assim, ante a lacuna legislativa entáo detectada (inexistência de regra que impedisse o recebimento da herança por Elmer Palmer), a Corte de Apelação decidiu o caso em questão (um autêntico hard case) não com base em uma regra, mas, sim, aplicando o princípio segundo o qual ninguém pode se beneficiar da própria torpeza.

Dworkin (2002, p. 39), na obra Levando os Direitos a Sério, assinala que as regras, diferentemente dos princípios, são aplicadas pelo método do "tudo-ou-nada", ou seja, possuem uma dimensáo de validade, significando dizer que, presentes os fatos que as mesmas estabelecem, a aplicação da regra será considerada: a) válida (e, por conseguinte, a consequência normativa prevista deverá ser igualmente aceita) ou b) inválida, em nada contribuindo para a decisão a ser tomada. Os princípios, por seu turno, não ostentam a aludida estrutura inerente às regras, tendo em vista que não estabelecem as condiçóes cuja ocorrência torna obrigatória a sua aplicação. 
Dworkin assinala que o Positivismo Jurídico tradicional simplifica o Direito descrevendo-o como um conjunto de regras que são válidas ou inválidas com respeito a um critério de pertencimento ou pedigree formal a partir do qual a sua validade ou invalidade é mensurada. Pontua, assim, que o Direito não opera dessa maneira, pois existem referências diferentes das regras, tais como os princípios e as políticas que escapam a essa medida. [...].

Conforme sustenta, ao menos em termos exclusivos nesta fase, o Direito é um conjunto de regras e de princípios morais; princípios estes que não são remissíveis a um critério de validade como o da regra de reconhecimento de Hart. A isso, agrega uma série de informaçóes.

A primeira delas é que as regras são normas aplicáveis na forma "ou tudo ou nada”, pois elas são aplicáveis apenas quando surgem as condiçóes que elas próprias fixam. Já os princípios são normas que não firmam uma consequência jurídica precisa diante de uma circunstância igualmente precisa; eles expressam consideraçóes de justiça, eqüidade ou outras dimensões da moralidade, ou seja, princípios não estabelecem uma solução unívoca para as controvérsias em que são aplicáveis, de tal modo que diferem das regras em sua operacionalidade lógica. [...].

De mais a mais, os princípios se caracterizam pela "dimensão de peso" ou de "importância”, não determinando um resultado em específico, pois eles são "razôes" que "guiam" e devem ser considerados quando as decisôes jurídicas são tomadas, mesmo que, para tanto, devam ser submetidos a um "balanceamento" frente a outros princípios que concorrem como razóes contextuais para o caso.

[...] Dworkin acrescenta ainda o fato de os princípios serem mais fracos que as regras no sentido de admitirem sempre incontáveis exceçóes, ao passo que, quando se trata das regras, as exceçóes que comportam podem ser enumeradas (SGARBI, 2006, p. 151-152).

Refletindo a respeito dos denominados casos difíceis, afirma Dworkin que a decisão tomada pela Corte (em Riggs versus Palmer) não se fundamentou em uma regra, mas em um princípio ("ninguém pode se beneficiar de seus próprios delitos"), cuja essência não fixa as condiçóes que tornam sua aplicação necessária; ao invés disto, tal princípio tão somente exprime a razão que conduz o argumento em determinada direção, motivo pela qual sua concretização requer uma decisão particular. Em casos assim, consoante afirmam Bittar e Almeida (2011, p. 487), 
cumpre ao "juiz proceder a uma escolha”, recorrendo, para tanto, "a critérios de justiça (justice) externos à ordem jurídica concreta, abrindo caminho para decisóes polêmicas que parecem convidar o jurista a pensar os limites entre Direito e política”.

De qualquer forma, esclarecem os referidos autores, a resposta de Dworkin para tal "perplexidade não reafirma as teses positivistas e muito menos abre campo para um autorizativo indeterminado para que o juiz proceda simplesmente conforme seu arbítrio". Entende o pensador norte-americano que um "sistema somente pode ser considerado coerente e completo se avaliados os princípios que a ele pertencem", de modo que o sistema somente funciona porque há princípios que o completam, “o que por si só é argumento bastante para informar ao juiz que o seu papel crítico não está em reproduzir regras do ordenamento, repetir a lógica dos julgados anteriores, nem mesmo criar como se fosse legislador, mas sim ponderar o peso dos valores que estão em debate, especialmente diante de situaçóes limite ou de hard cases" (BITTAR; ALMEIDA, 2011, p. 487).

Isso posto, Dworkin afirma que o modelo concebido pelo Positivismo de Hart, por ser integrado apenas por regras, acaba por ensejar um problema, tendo em vista que estas nem sempre são suficientes para proporcionar uma solução para os casos difíceis, motivo pelo qual propóe um arquétipo igualmente constituído por principios.

\section{LON LUVOIS FULLER E A MORALIDADE INTERNA DO DIREITO}

Lon Luvois Fuller (1902-1978), norte-americano, é conhecido no Brasil pela obra $O$ Caso dos Exploradores de Cavernas, cuja leitura é quase que obrigatória para os alunos que ingressam no curso de Direito. No que interessa ao tema ora abordado, cumpre registrar que Lon Fuller entende que o Direito ostenta uma moralidade interna, proposta teórica construída no âmbito de sua principal obra jusfilosófica, cujo título é A Moralidade do Direito (The Morality of Law, 1964), na qual o ilustre pensador "apresenta de forma mais sistemática as suas consideraçôes contra o Positivismo e propóe de maneira mais desenvolvida sua versão peculiar e secular de Direito Natural” (MARCONDES; STRUCHINER, 2015, p. 109). 
Para Fuller, o Direito é um método ético de se criar e assegurar uma forma para as relações sociais. As regras jurídicas são expressivas: cada regra contém um objetivo voltado para a concretização de algum valor da ordem jurídica, e desse modo "uma regra é ao mesmo tempo um fato e um critério para avaliação dos fatos" [...] (MORRISON, 2012, p. 460).

Lon Fuller, em A Moralidade do Direito, estabelece uma distinção entre o que denomina de moralidade do dever e de moralidade da aspiração. A moralidade do dever, explica o autor, "estipula as regras básicas sem as quais uma sociedade organizada é impossível, ou sem as quais uma sociedade organizada e voltada para certos fins específicos deve errar o alvo"; tal moralidade, prossegue Fuller, "não condena os homens por perderem as oportunidades da mais plena realização de seu potencial”, mas, em vez disso, "condena-os por não respeitarem as exigências fundamentais da vida social." A moralidade da aspiraçâo, por seu turno, condiz com a "moralidade do bem-viver, da excelência, da mais plena realização das potencialidades humanas" (MORRISON, 2012, p. 462), cabendo ressaltar que, sob um prisma hierárquico, a moralidade da aspiração encontra-se num plano superior.

Morrison (2012, p. 460-461) destaca que Fuller “criou uma forma secular de direito natural, que definia o Direito como atividade humana dotada de propósito consciente", tendo acusado o Positivismo Jurídico de várias imperfeiçôes. Segundo Morrison, na ótica de Fuller, os autores positivistas (tais como Bentham, Austin e Kelsen) "recusavam-se a atribuir ao Direito qualquer objetivo, por mais modesto e restritivo". Assim, "por estarem exclusivamente preocupados em descrever o Direito como este era, acreditavam que nada podiam dizer, em termos científicos, sobre como deveria ser o Direito".

Prosseguindo em suas críticas ao modelo juspositivista, Fuller opóe-se à concepção hartiana, notadamente por entender que o Direito transcende o sistema de regras idealizado por Hart, devendo, pois, abrir-se para a ética e a metafísica. Um dos debates travados entre estes dois grandes pensadores é registrado por Marcondes e Struchiner, ora transcrito:

Outro ponto de discordância entre os autores, agora mais centralmente ligado às relações entre Direito e moral, diz respeito a certos casos que surgiram depois da Segunda Guerra Mundial. Terminado o conflito, os tribunais da Alemanha se viram diante da questão de como lidar com os atos de extrema injustiça 
realizados dentro dos contornos da lei nazista. Um caso específico foi o de uma mulher que denunciou o marido, do qual queria se ver livre, por ter falado mal do regime, algo que era proibido de acordo com a lei e que poderia levar à pena de morte. $\mathrm{O}$ homem foi condenado e obrigado a lutar no front, onde acabou sendo morto. Depois da guerra, a mulher foi processada por ter justamente constrangido a liberdade do marido. Fuller defendeu a decisão da Corte que estabeleceu que a lei nazista seria nula, e que nunca teria feito parte do Direito. Hart, por sua vez, que defendia a separação entre Direito e moral, dizia que tal solução era um engodo: para ele era claro que a lei nazista era juridicamente válida, apesar de grosseiramente imoral. Ser juridicamente válida não implicava força moral absoluta. Para Hart, o juiz deveria encarar o problema enquanto um problema moral, com toda a sua complexidade. Segundo ele, em certos casos juízes devem assumir que estão tomando uma decisão moral contrária ao Direito por ser a coisa certa, e não fazer uso de subterfúgios para esconder o fato de que a decisão possui uma pintura moral. Fuller, por sua vez, achava que o sistema de leis de um regime ditatorial como o regime nazista não observava o que ele chamava de "moralidade interna do Direito", o conjunto de critérios mínimos capazes de garantir a juridicidade, ou existência jurídica, de certas leis. Em suma, Hart e Fuller concordam com a condenação da mulher que denunciou o marido, mas discordam da justificativa para tal (MARCONDES; STRUCHINER, 2015, p. 108).

Assinala Vieira (1999, p. 37-46) que um dos objetivos perseguidos por Fuller na obra The Morality of Law reside exatamente no "estabelecimento de um conceito de estado de direito que possa ser utilizado como escala para medir a qualidade intrínseca dos sistemas jurídicos”, ou seja, o referido pensador estadunidense objetivou "criar uma versáo paradigmática de estado de direito como instrumento cognitivo, distinto de parâmetros substantivos de justiça e de noçóes de direito natural, para servir como padrão de avaliação dos sistemas jurídicos [...]." Na visão de Fuller, prossegue Vieira, "a perspectiva positivista que entende a lei como um fato de autoridade, e não como um empreendimento propositivo moral, perde qualquer capacidade normativa para checar o cumprimento do ideal de legalidade pelo sistema jurídico”.

Fuller deriva seu modelo normativo de uma série de condiçôes sociais. Neste sentido, indica quais são os elementos para a construção de um estado de direito. 
Para ele, o modesto propósito dos sistemas legais é submeter "a conduta humana à orientação e controle de regras gerais" [...]. Para alcançar este propósito, os sistemas legais deveriam incorporar uma série de elementos, ou "excelências", que constituiriam a "moralidade interna do direito". A primeira destas excelências é a própria existência de regras. Estas também devem ser públicas, prospectivas, não contraditórias entre si, compreensiveis e estáveis para que as pessoas possam se pautar por elas. A última excelência que compóe a moralidade interna do direito é a congruência entre as regras e sua efetiva administração e aplicação. São estas, portanto, as oito "excelências" que compóem a essência do estado de direito [...] (VIEIRA,1999, p. 37-46).

No mesmo sentido, Morrison (2012, p. 460-461) elenca as seguintes excelências relacionadas por Fuller: "as leis devem ser suficientemente gerais; publicamente elaboradas; prospectivas; compreensíveis; não contraditórias; razoavelmente constantes; possíveis quanto ao desempenho; administradas por autoridades de acordo com seu conteúdo, e deve haver congruência entre ação oficial e regra declarada”. A respeito de tais elementos apontados por Fuller, e no âmbito de uma perspectiva comparativa com a perspectiva hartiana, afirma Stolz (2007, p. 101-120) que, diferentemente daquele, "Hart não cria um catálogo de elementos considerados essenciais para a existência e funcionamento do Direito", mencionando somente alguns avaliados como "imprescindíveis, dando-lhes o nome de 'princípios de legalidade', a saber: a generalidade e a perdurabilidade das normas jurídicas (elementos compatíveis com a moral interna do Direito de Fuller)".

\section{WILFRID J. WALUCHOW E A DIVISÃO NO POSITIVISMO JURÍDICO CONTEMPORÂNEO}

Wilfrid J. Waluchow é um pensador canadense e ex-aluno de Herbert Hart em Oxford. No âmbito da Filosofia do Direito, e mais precisamente no que é pertinente à presente digressão, forjou a conhecida expressão Positivismo Inclusivo, em contraste com o denominado Positivismo Exclusivo. Na obra Positivismo Juridico Inclusivo (Inclusive Legal Positivism, 1994), Waluchow procura demonstrar como a validade das normas jurídicas pode depender de consideraçóes morais. 
Em uma breve sinopse distintiva, a ala inclusivista (Hebert Hart, Jules Coleman e Wilfrid Waluchow) admite a possível inserção de valores morais no Direito, em contraposição ao segmento exclusivista (Joseph Raz), que não acolhe tal possibilidade. Os adeptos do viés positivista inclusivista, segundo assevera Dimoulis (2006, p. 137, 139), "consideram que os valores morais não são sempre decisivos para definir e aplicar o Direito", embora admitam que, "em certas sociedades, pode haver uma convenção social impondo levar em consideração a moral para determinar a validade e para interpretar normas jurídicas", o que demonstra que os defensores de tal concepção "acreditam na possível existência de sistemas jurídicos que adotam 'critérios de juridicidade de cunho moral'”, razão pela qual é adequado afirmar que tal manifestação positivista, apesar de não refutar "a tese da separação entre Direito e moral”, "considera possível a existência de sistemas jurídicos nos quais os imperativos morais desempenhem um papel crucial na identificação da validade das normas jurídicas e, principalmente, em sua interpretação." Com efeito, em termos gerais, conforme também assinala Dimoulis (2006, p. 139), a principal dissensão entre ambos os matizes positivistas reside exatamente na posição ocupada pela moral em um dado sistema jurídico. Enquanto que para a abordagem exclusivista "a moral nunca constitui condição de definição do Direito", a perspectiva inclusivista, ao contrário, argumenta que a moral, embora não possa ser concebida como uma conditio sine qua non da significação do Direito, pode cumprir tal função em determinados sistemas jurídicos.

Dimoulis (2006, p. 142), ao analisar criticamente as premissas do Positivismo Jurídico Inclusivo, assevera ser indiferente afirmar que o operador do Direito deve utilizar critérios morais quando da interpretação do material jurídico, posto que tal afirmação não aponta os preceitos morais a serem utilizados por ocasiáo da concretização das normas jurídicas abstratas e, especialmente, "não indica se aquilo que será apresentado como moralmente certo pela autoridade competente corresponde a uma exigência moral ou simplesmente decorre de preferências políticas do aplicador". Assim sendo, segundo o referido autor, o problema do Positivismo Jurídico Inclusivo reside justamente em acolher propostas teóricas tipicamente pertinentes ao denominado moralismo jurídico. 
Ainda na esfera crítica, Dimoulis reconhece que o Positivismo Jurídico Exclusivo, ao negar a influência da moral, "tende a admitir a existência de uma grande liberdade de decisão do aplicador, já que, em caso de dúvida interpretativa, de lacuna ou de norma de baixa densidade normativa, ele decidirá exercendo um poder próprio". Nesse sentido, Joseph Raz, demonstrando a sua concepção positivista exclusivista, afirma:

Se um problema jurídico não pode ser respondido mediante padróes que derivam de fontes legais, então não há resposta jurídica. Nesse caso, o Direito não é posto. Decidindo sobre tais problemas, os tribunais devem necessariamente adentrar em um novo espaço (jurídico) e sua decisão faz evoluir o Direito (JOSEPH RAZ apud DIMOULIS, 2006, p. 140).

Ao discorrer sobre a concepção (relativa ao Positivismo Jurídico Exclusivo) de Raz, Dimoulis (2006, p. 146) registra que a "tese da exclusão da moral da definição do Direito possui uma versão extrema, se for entendida como um mandamento de ignorar a moral no momento de criação do Direito", consignando, ainda, que o Positivismo Jurídico (em sentido estrito) "não tem motivos para afirmar que a moral não deve influenciar o Direito no momento de sua criação, pois tal afirmação normativa sobre o conteúdo do Direito não condiz com a pretensão descritiva”.

Ainda sobre o denominado Positivismo Juridico Exclusivo, Dimoulis (2006, p. 135) explana que, de acordo com tal vertente, a moral não pode ser utilizada como critério de identificação do Direito Positivo, seja no que se refere à constatação de sua validade, seja no âmbito de sua interpretação, aspecto que permite inferir "uma rigorosa tese da separação entre Direito e moral". Neste contexto, segundo a explicação de Dimoulis, a moral nunca interfere conceitualmente na definição do Direito:

Para o PJE [Positivismo Jurídico Exclusivo], o Direito é estabelecido única e exclusivamente por fatos sociais. Para constatar sua existência e conteúdo é suficiente observar as condutas humanas que o criam como convenção social. Mesmo quando o juiz cria uma nova norma para preencher lacunas ou por qualquer outro motivo e decide de acordo com crenças morais, não temos uma influência da moral no Direito. Estamos diante de uma decisão humana que 
constitui um fato social. Essa decisão não cria direito porque é justa, moral ou adequada, mas por que a pessoa ou grupo que formulou essa vontade possui autoridade para tanto (DIMOULIS, 2006, p. 135).

Destarte, Dimitri Dimoulis adverte que mesmo que uma norma jurídica refira-se expressamente à moral, tal fato não possui o condáo de "juridificá-la", tendo em vista que o "único elemento juridicamente relevante é a norma que foi criada por uma fonte autorizada, independentemente de seu conteúdo e das intençóes de seu criador".

\section{CONCLUSÃO}

A questão que envolve os denominados Jusnaturalismo e Juspositivismo (e seus respectivos contrastes teóricos) tem inspirado, ao longo do tempo, as reflexões de juristas e filósofos, tal como fizeram Bentham, Austin, Kelsen, Ross, Hart, Dworkin, Fuller, Walluchov e outros. Muito embora possamos afirmar, com relativa segurança, que grande parte das históricas e antigas controvérsias associadas ao confronto entre o Direito Positivo e o Direito Natural já tenham sido superadas, subsistem, ainda, inúmeros aspectos teóricos que merecem uma dedicação acadêmica por parte de qualquer escrito que se disponha a abordar este assunto.

Assim, não obstante opiniôes divergentes, as quais pugnam pelo enfraquecimento teórico do tema vertente, o passar dos séculos, desde a Antiguidade Clássica, transitando pela Idade Média e chegando até a época atual, demonstra justamente o contrário, posto não ter conseguido eliminar a estima dos pensadores pela temática desenvolvida no presente texto, dado historicamente concreto que revela a própria tensão conceitual (e concernentes desdobramentos) que existe entre ambos os fenômenos.

\section{REFERÊNCIAS}

AGUIAR, Roger. O positivismo e o pós-positivismo na criação e aplicação do direito civil brasileiro. In: CLEYSON MELLO, Novos Direitos: os paradigmas da pós-modernidade. Niterói: Impetus, 2004. 
BARZOTTO, Luiz Fernando. O positivismo jurídico contemporâneo: uma introdução a Kelsen, Ross e Hart. Porto Alegre: Livraria do Advogado, 2007.

BITTAR, Eduardo C. B.; ALMEIDA, Guilherme A. de. Curso de Filosofia do Direito. 9. ed. São Paulo: Atlas, 2011.

BOBBIO, Norberto. O positivismo jurídico, lições de filosofia do Direito. Compilação de Nello Morra. Trad. e notas de Márcio Pugliese, Edson Bini e Carlos E. Rodrigues. São Paulo: Ícone, 1995.

BUGALLO, Alejandro Alvarez. Teses básicas do positivismo e suas críticas ao jusnaturalismo. Lex Humana, n. 2, 2009.

CASTILHO, Ricardo. Filosofia do Direito. 4. ed. São Paulo: Saraiva, 2017.

DANTAS, Marcus. Jurisprudência dos conceitos. In: BARRETTO, Vicente de Paulo (Coord.). In: Dicionário de Filosofia do Direito. Rio de Janeiro: Renovar, 2006.

DIAS, Maria Cristina Longo Cardoso. O Direito e a ética em Bentham e Kant: uma comparação. Trans/Form/Açâo, Marília, v. 38, n. 1, p. 147-166, jan./abr. 2015.

DIMOULIS, Dimitri. Positivismo jurídico - introdução a uma Teoria do Direito e defesa do pragmatismo jurídico-político. São Paulo: Método, 2006 (Coleção Professor Gilmar Mendes).

DINIZ, Maria Helena. Compêndio de introdução à Ciência do Direito. 12. ed. São Paulo: Saraiva, 2000.

DWORKIN, Ronald. Levando os Direitos a Sério. Tradução Nelson Boeira. São Paulo: Martins Fontes, 2002.

EDMUNDSON, William A. Uma introdução aos Direitos. São Paulo: Martins Fontes, 2006. FERRAZ JR., Tercio Sampaio. Introduçâo ao Estudo do Direito, técnica, decisão, dominação. 8. ed. São Paulo: Atlas, 2015.

HART, Hebert L. A. O conceito de Direito. São Paulo: Martins Fontes, 2009.

KELSEN, Hans. Teoria Pura do Direito. Tradução João Baptista Machado. 2. ed. São Paulo: Martins Fontes, 1987.

. Teoria geral do Direito e do Estado. São Paulo: Martins Fontes, 1990.

LARENZ, Karl. Metodologia da Ciência do Direito. Trad. José Lamego. Lisboa: Calouste Gulbenkian, 1997.

MARCONDES, Danilo; STRUCHINER, Noel. Textos básicos de Filosofia do Direito - de Platão a Frederick Schauer. Rio de Janeiro: Zahar, 2015. 
MARCONDES, Danilo; STRUCHINER, Noel. Textos básicos de ética - de Platão a Foucault. Rio de Janeiro: Zahar, 2007.

MORRISON, Wayne. Filosofia do Direito - dos gregos ao pós-modernismo. Tradução Jefferson Luiz Camargo. São Paulo: Martins Fontes, 2012.

NADER, Paulo. Introdução ao Estudo do Direito. 39. ed. Rio de Janeiro: Forense, 2017. . Filosofia do Direito. 19. ed. Rio de Janeiro: Forense, 2010.

REALE, Miguel. Lições preliminares de Direito. 26. ed. São Paulo: Saraiva, 2002.

SGARBI, Adrian. Teoria do Direito, primeiras liçóes. Rio de Janeiro: Lumen Juris, 2007. . Clássicos de Teoria do Direito. Rio de Janeiro: Lumen Juris, 2006.

SOARES, Ricardo M. F. Elementos de Teoria Geral do Direito. São Paulo: Saraiva, 2013.

STOLZ, Sheila. Um modelo de positivismo jurídico: o pensamento de Herbert Hart. Revista de Direito da FGV, v. 3, n. 11, jan./jun. 2007.

STRUCHINER, Noel. Para falar de regras - o positivismo conceitual como cenário para uma investigação filosófica acerca dos casos difíceis do Direito. 2005. Tese (Doutorado) Departamento de Filosofia, PUC-Rio, Rio de Janeiro, 2005.

VENOSA, Sílvio. Introdução ao estudo do Direito - primeiras linhas. 2. ed. São Paulo: Atlas, 2006.

VIEIRA, Oscar Vilhena. Desigualdade e limites do governo das leis. São Paulo em Perspectiva, 13 (3), p. 37-46, 1999. 